\title{
ZWIĄZEK MIĘDZY BEZROBOCIEM A INFLACJA W POLSCE NA TLE KRZYWEJ PHILLIPSA
}

\section{WPROWADZENIE}

W 2008 r. minęło pół wieku od przedstawienia pierwszych analiz statystycznych, dokonanych przez A. W. Phillipsa, które - po burzliwej debacie w kolejnych latach doprowadziły do wykrystalizowania się w teorii ekonomii terminu ,,krzywa Phillipsa”. Pojęcie to przetrwało do dziś zarówno w wymiarze badawczym, jak i dydaktycznym. Stanowi zarówno przedmiot ożywionej dyskusji naukowej, jak i jeden z ważniejszych tematów wykładowych z makroekonomii oraz przedmiotów pokrewnych. Pojęcie to stało się impulsem do prowadzenia badań zarówno w ramach nurtu teoretycznego związanego z keynesizmem, jak i ekonomia neoklasyczną. Koncepcja krzywej Phillipsa została wysunięta w ramach syntezy neoklasycznej i była wówczas postrzegana jako istotny element keynesizmu ${ }^{1}$. Jednak jej dalsza ewolucja w teorii ekonomii i konfrontacja tego dorobku z praktyką gospodarczą spowodowały, że „odegrała decydującą rolę w rozpadzie keynesistowskiego konsensusu. [...] Miała ona zwieńczyć gmach keynesizmu, w rzeczywistości okazała się dla niego przysłowiowym koniem trojańskim"2.

Ze względu na swoją wartość naukową koncepcja krzywej Phillipsa inspirowała i nadal inspiruje wielu badaczy. Dotychczasowy dorobek stanowi fundament dalszego rozwoju tej koncepcji i wzbogacania jej o nowe, nie poruszone dotąd kwestie. W pracy przedstawiono poglądy wybranych ekonomistów, którzy potwierdzili swoimi badaniami wysoką wartość stawianych tez i formułowanych poglądów, chociaż często kontrowersyjnych.

W niniejszym artykule postawiono zarówno cel teoretyczny, jak i cel empiryczny. Celem teoretycznym jest pokazanie ewolucji zmian w postrzeganiu istoty krzywej Phillipsa w ciąu całego, trwającego ponad pół wieku okresu badań. Część teoretyczna pracy koncentruje się na zarysowaniu początków krzywej Phillipsa, wskazując na podstawowe cechy modelu opracowanego przez A. W. Phillipsa oraz wątki rozwijane i uzupełniane w kolejnych latach przez P. Samuelsona i R. Solowa. Następnie przedstawiono koncepcję M. Friedmana

${ }^{1}$ E. Kwiatkowski, Bezrobocie. Podstawy teoretyczne, WN PWN, Warszawa 2002, s. 140.

${ }^{2}$ A. Wojtyna, Ewolucja keynesizmu a gtówny nurt ekonomii, WN PWN, Warszawa 2000, s. 107. 
i E. Phelpsa - długookresową krzywą Phillipsa oraz rozważania dotyczące zjawiska naturalnej stopy bezrobocia i hipotezy oczekiwań adaptacyjnych. Dalej omówiono genezę i rozwój dwukierunkowej ewolucji poglądów na krzywą Phillipsa w latach 70. XX w. - z jednej strony badanej przez neokeynesistów, z drugiej - przez szkołę racjonalnych oczekiwań. Teoretyczny dyskurs kończy omówienie kwestii dalszego rozłamu koncepcji krzywej Phillipsa, wykorzystujące dorobek nowej ekonomii klasycznej, teorii realnego cyklu koniunkturalnego oraz teorii nowej syntezy neoklasycznej.

Z kolei celem empirycznym jest próba ustalenia przydatności krzywej Phillipsa do oceny ujemnej zależności między inflacją a bezrobociem w gospodarce polskiej w latach 1990-2010. Ze względu na tak nakreślony zakres analizy empirycznej, sprawdzono kierunek i siłę związku między stopą bezrobocia a inflacją dla danych rocznych, kwartalnych, półrocznych i rocznych.

\section{ROZWÓJ KONCEPCJI KRZYWEJ PHILLIPSA W TEORII EKONOMII}

\section{Geneza „krzywej Phillipsa”}

Pomysł postrzegania bezrobocia i inflacji jako zjawisk wzajemnie na siebie oddziałujących jest starszy niż rozważania A. W. Phillipsa ${ }^{3}$, I. Fischer bowiem zajmował się tą problematyką już w latach 20. ubiegłego wieku. Jednak to właśnie A. W. Phillips dokonał najbardziej znaczacych obserwacji w sferze wzajemnych oddziaływań inflacji i bezrobocia, analizując gospodarkę Wielkiej Brytanii w blisko stuletnim okresie: $1861-1957^{4}$. Analizując zmiany zachodzące w wysokości stopy inflacji i bezrobocia, A. W. Phillips doszedł do trzech istotnych wniosków. Po pierwsze, zauważył, że istnieje odwrotna relacja między stopą bezrobocia a poziomem płac nominalnych przy silnej sztywności płac „od dołu”. Analiza kształtowania się wysokości płac i stopy zatrudnienia pozwoliła A. W. Phillipsowi na postawienie drugiej istotnej tezy, a mianowicie, że zmiana płac zależy nie tylko od bieżącego poziomu bezrobocia, ale też od jego tempa zmian. Trzecim spostrzeżeniem A. W. Phillipsa było wskazanie na zależność między zmianą wysokości płac a stopa inflacji. Powyższe spostrzeżenia pozwoliły A. W. Phillipsowi skonstruować model ilustrujący zależność pomiędzy inflacja płac (dynamika zmian płac nominalnych) a bezrobociem. Model ten ujmował także relację popytowa, wskazując, że wzrost popytu na rynku pracy podnosi wartość wynagrodzeń.

Przypominając rozważania A. W. Phillipsa, celowo użyto określenia „,model Phillipsa", ponieważ ówczesna zależność ilustrująca relację między inflacją cen i płac a bezrobociem, stanowiąca odkrycie A. W. Phillipsa, nie nosiła jeszcze w 1958 r. nazwy „krzywej”. Pojęcie „krzywa Phillipsa” wprowadzili do ekonomii

\footnotetext{
${ }^{3}$ T. M. Humphrey, The Evolution and Policy Implications of Phillips Curve Analysis, Federal Reserve Bank of Richmond, „Economic Review” 1985, March/April, s. 3.

${ }^{4}$ A. W. Phillips, The Relation between Unemployment and the Rate of Change of Money Wage Rates in United Kingdom, 1861-1957, „Economica” 25, 1958, nr 100, s. 283-299.
} 
P. Samuelson i R. Solow. Mimo różnic w poglądach ekonomicznych (R. Solow przedstawiciel ekonomii neoklasycznej, P. Samuelson - neokeynesista), badacze ci zgodnie współpracowali przy odkryciu na początku lat 60 . XX w. zależności między inflacją a bezrobociem $\mathrm{w}$ gospodarce USA ${ }^{5}$. W swoim artykule wysunęli tezę o istnieniu zależności między tempem wzrostu płac nominalnych a tempem wzrostu cen. Na tej podstawie krzywa Phillipsa stała się ilustracja ujemnej relacji szeroko rozumianej inflacji (nie tylko inflacji płac - tak jak według A. W. Phillipsa) i bezrobocia w krótkim okresie.

\section{Ewolucja krzywej Phillipsa: długi okres i oczekiwania inflacyjne}

Model stworzony przez A. W. Phillipsa, a wzbogacony merytorycznie przez P. Samuelsona i R. Solowa, był jednak wciąż modelem niepełnym. Krytykę tego modelu wyrazili $w$ swych badaniach przede wszystkim M. Friedman i E. Phelps. W ramach modelu Friedmana-Phelpsa należy zwrócić uwagę na dwa rodzaje stóp inflacji. O ile w modelu Phillipsa i Samuelsona-Solowa występowało zjawisko inflacji faktycznej, o tyle w modelu Friedmana-Phelpsa pojawiła się dodatkowo inflacja oczekiwana. M. Friedman zasugerował, że inflacja oczekiwana ma związek ze sposobem odbioru przez podmioty zmian cen rynkowych (inflacyjnych). Zgodnie $\mathrm{z}$ dotychczasowym rozumieniem mechanizmów ekonomicznych podmioty rynkowe opierały swe decyzje na podstawie analizy zjawisk zachodzących $\mathrm{w}$ przeszłości. Zachowanie takie - zdaniem M. Friedmana - rodziło jednak niebezpieczeństwo tak zwanej iluzji pieniądza, gdyż w warunkach wzrostu inflacji podmioty mogą utożsamiać wzrost inflacji ze zwiększeniem realnej wartości pieniądza. W nowym ujęciu podmioty rynkowe powinny podejmować decyzje na podstawie prognoz i myślenia wyprzedzającego. Jeśli prognozy są słuszne, to podmioty szybciej spostrzegaja, że państwo zwiększa podaż pieniądza. W efekcie wzrost inflacji zniweluje chwilową wyższą aktywność podmiotów gospodarczych. W opinii M. Friedmana, polityka ekonomiczna nie może kształtować stopy bezrobocia, zwanej naturalną stopa bezrobocia, która jest zależna od mikroekonomicznej struktury rynku pracy i produkcji.

Mimo obserwowanych różnic doktrynalnych (M. Friedman - monetarysta, E. Phelps - neokeynesista) naukowcy ci wypracowali spójną koncepcję rozszerzająca dotychczasowy model krzywej Phillipsa, tworząc w teorii ekonomii tak zwaną długookresową krzywą Phillipsa (znaną również jako model Friedmana-Phelpsa). M. Friedman wysunął tezę, że polityka monetarna może utrzymać bezrobocie na niezmienionym poziomie tylko w krótkim okresie ${ }^{6}$. Odniósł się on zatem krytycznie do długookresowej skuteczności modelu Phillipsa. Jego argumentacja opierała się na tym, że wzrost podaży pieniądza powoduje jednoczesne zwiększenie popytu na pracę i wzrost cen (wynagrodzeń), a tym samym wzrost inflacji, a zatem w długim okresie nie wpływa na wielkość stopy bezrobocia. Wzrost podaży pieniądza tylko chwilowo zmniejsza

\footnotetext{
5 P. Samuelson, R. Solow, Analytical Aspects of Anti-Inflation Policy, ,American Economic Review Papers and Proceedings" 50, 1960, s. 177-194.

${ }^{6}$ M. Friedman, The Role of Monetary Policy, „American Economic Review” 58, 1967, s. 1-17.
} 
bezrobocie, natomiast bezrobocie długookresowe pozostaje tożsame ze stanem bezrobocia naturalnego.

Z kolei E. Phelps skupił się na analizie przyczyn tarć w ustalaniu wysokości płac i cen ${ }^{7}$. W jego opinii, zarówno przedsiębiorstwa, jak i pracownicy obserwuja wzrost cen i płac w określonym sektorze oraz zwiększają produkcyjność, nie zauważając, że wzrost cen nastąpił w całej gospodarce. Dodatkowo E. Phelps założył, że skoro na rynku pracy istnieje bezrobocie frykcyjne, a każda firma podnosi płace, to pracownicy nie zmienia pracy na lepiej płatną. Zatrudnieni pracownicy są wciagnięci $\mathrm{w}$ redukcję bezrobocia frykcyjnego, a makroekonomiczne dane wskazuja na spadek stopy bezrobocia. Zjawisko to występuje jedynie przez krótki okres, kiedy oczekiwania inflacyjne są nieprawidłowe: gdy stopa oczekiwanej inflacji jest niższa niż stopa inflacji rzeczywistej (realnej).

\section{Rozłam doktrynalny lat 70. XX w. - dwukierunkowy rozwój teorii krzywej Phillipsa. Ewolucja modelu Friedmana-Phelpsa w latach 70. XX w.}

Do dorobku M. Friedmana i E. Phelpsa nawiązywać zaczęła w późniejszych latach głównie myśl neokeynesowska. Neokeynesowski model krzywej Phillipsa wskazywał, że określona relacja faktycznej stopy inflacji do oczekiwanej jest efektem nie tylko zmian oczekiwań podmiotów gospodarczych, ale również procesu wolnego dostosowywania się płac i cen $^{8}$. Nurt poneokeynesowski był jedna z dróg ewolucji krzywej Phillipsa - modelu opartego na koncepcji Phillipsa, a także Samuelsona-Solowa, wyraźnie uznającego znaczny wkład myśli monetaryzmu. W latach 70. XX w. model Friedmana-Phelpsa stał się obiektem krytyki. Przedmiotem sporów była kwestia wzrostu oczekiwanej stopy inflacji, której wysokość mogła zależeć od obecnych lub przyszłych zmian w polityce. Dlatego też neokeynesiści stworzyli postulat (wynikający z hipotezy naturalnej stopy bezrobocia Friedmana-Phelpsa) głoszący, że wybór przez rząd określonej, krótkookresowej kombinacji stopy inflacji i stopy bezrobocia ma wpływ na oczekiwania podmiotów gospodarczych, prowadząc do zmiany punktu równowagi (rozumianego tutaj jako relacja inflacji i bezrobocia) w gospodarce.

W ramach dwukierunkowego rozwoju teorii krzywej Phillipsa w latach 70. $\mathrm{XX}$ w. ważne miejsce - obok nurtu neokeynesowskiego - odegrała teoria racjonalnych oczekiwań rozwinięta przez R. E. Lucasa. W 1972 r. przedstawił on pogląd, że na określone położenie krzywej Phillipsa kluczowy wpływ wywieraja oczekiwania podmiotów rynkowych ${ }^{9}$. Według jego analiz, podmioty rynkowe charakteryzują się tak zwanymi racjonalnymi zachowaniami, dążąc w każdych warunkach do maksymalizacji użyteczności. Zakładając, że podmioty te mają wszelkie dane o czynnikach wpływających na przebieg zjawisk

\footnotetext{
${ }^{7}$ E. Phelps, Phillips Curve, Expectation of Inflation and Optimal Unemployment over Time, „Economica” 34, 1967, nr 135, s. 254-281.

${ }^{8}$ R. J. Gordon, The History of the Phillips Curve: An American Perspective, Northwestern University, Evanston, IL, 2008, s. 22-28.

9 R. E. Lucas, Expectations and the Neutrality of Money, ,,Journal of Economic Theory” 4, 1972, nr 2, s. 103-124.
} 
gospodarczych, znany jest im istniejący (bieżący) model gospodarczy. Wiedza ta, w połączeniu z informacjami z przeszłości (na temat kształtowania się wpływu inflacji i bezrobocia na równowagę rynkową) pozwala podmiotom na formułowanie oczekiwań dotyczących przyszłości. W wypadku trafnych prognoz podmiotów i elastycznych cen na rynku będzie zachodzić równowaga. Zdaniem R. E. Lucasa, efekt nierównowagi występuje sporadycznie, będąc wynikiem niemożliwych do przewidzenia zdarzeń. Zatem zmiana podaży pieniądza nie wywołuje zmiany produkcji realnej i zatrudnienia, ponieważ podmioty na rynku wiedzą, że realne ceny nie ulegna zmianie. O ile model Friedmana-Phelpsa opierał się na zjawiskach ciągłości rynku i niedoskonałości informacji, o tyle R. E. Lucas rozszerza ten model o dodatkowy element na drodze ewolucji krzywej Phillipsa: propozycję zastąpienia wolno dostosowujących się oczekiwań właśnie oczekiwaniami racjonalnymi. R. E. Lucas wierzył, że żaden podmiot uczestniczący w grze rynkowej nigdy nie popełnia dwa razy tego samego błędu, co świadczy o odmiennym od neokeynesistów spojrzeniu na kwestię oczekiwań.

Model neokeynesowski traktujący oczekiwania podmiotów jako czynnik egzogeniczny (a więc zewnętrzny, niezwiązany z gospodarką) jest - zdaniem R. E. Lucasa - modelem ilustrującym procesy gospodarcze i krzywa Phillipsa w sposób niepełny, przedstawia bowiem konsekwencje zmian oczekiwań, ale nie przyczyny tych zmian. Spostrzeżenia te, pokazujące odmienny pogląd na kształtowanie się równowagi gospodarczej i krzywej Phillipsa, doprowadziły $\mathrm{w}$ konsekwencji do przedefiniowania znaczenia państwa $\mathrm{w}$ gospodarce. W 1978 r. R. E. Lucas wraz z T. J. Sargentem odnieśli się we wspólnym artykule do zjawiska stagflacji w USA, spowodowanego przez szoki podażowe związane z kryzysem naftowym. Badacze ci jednoznacznie wskazali, że podmioty gospodarcze formułuja swoje oczekiwania na podstawie tych samych informacji, co decydenci odpowiedzialni za politykę ekonomiczna państwa, w rezultacie działaja tak, by neutralizować działania polityczne ingerujące $\mathrm{w}$ równowage gospodarczą ${ }^{10}$. R. E. Lucas i T. J. Sargent przedstawili w efekcie swoisty manifest szkoły racjonalnych oczekiwań w zakresie polityki ekonomicznej państwa. Za nadrzędny cel uznali dążenie rządu do utrzymania stabilności cen oraz wpływu państwa na wartość podaży. Zdaniem R. E. Lucasa i T. J. Sargenta, państwo nie ma wpływu na wzrost produkcji i zatrudnienia, co przejawia się właśnie w niskiej skuteczności aktywnej polityki stabilizacji wzrostu gospodarczego.

\section{Od teorii racjonalnych oczekiwań w kierunku nowej ekonomii klasycznej. Teoria realnego cyklu koniunkturalnego i nowa synteza neoklasyczna}

Model Phillipsa i Samuelsona-Solowa, najpierw poddany krytyce przez model Friedmana-Phelpsa, a następnie wzbogacony o dwukierunkową analizę neokeynesistów i model Lucasa-Sargenta, musiał zostać dostosowany do

${ }^{10}$ R. E. Lucas, T. J. Sargent, After Keynesian Macroeconomics, Federal Reserve Bank of Boston, Boston 1978, s. 49-72. 
gospodarki amerykańskiej drugiej połowy lat 70. XX w. Nurt racjonalnych oczekiwań, pozostający na obrzeżach ekonomii neoklasycznej i traktowany jako radykalna odmiana myśli monetarystycznej, nie wyjaśniał relacji między wielkością produkcji (zatrudnienia) a wysokością cen. Rewizji zostało także poddane zagadnienie miejsca i roli państwa w nowej (wzbogaconej o te ekstremalne doświadczenia gospodarcze lat 70. XX w.) amerykańskiej gospodarce rynkowej.

$\mathrm{Na}$ podstawie rodzącego się paradygmatu, opartego na teorii racjonalnych oczekiwań, powstał nurt znany we współczesnej ekonomii pod nazwą nowej ekonomii klasycznej (NEK). Nurt ten postulował takie działanie polityki ekonomicznej, które umiejętnie reaguje na szoki podażowe. NEK funkcjonowała $\mathrm{w}$ opozycji do założeń modelu neokeynesowskiego ${ }^{11}$, czego najpełniejszym wyrazem była teoria realnego cyklu koniunkturalnego. T. Sargent, wraz $\mathrm{z}$ R. Lucasem, przedstawił swoje stanowisko w kwestii wpływu polityki dyskrecjonalnej na kształtowanie się inflacji w latach 70. XX w. Wysunął on tezę, że decydenci odpowiedzialni za politykę ekonomiczną państwa nie są pewni położenia gospodarki na krzywej Phillipsa. Z tego powodu posługują się oni danymi opartymi na przeszłych wahaniach gospodarczych. Zatem w krótkim okresie wybór polityki dyskrecjonalnej oznacza w rzeczywistości wybór między pewną stopą inflacji a bezrobocia (a zatem zgodnie z tym, co ilustruje krzywa Phillipsa). Należy jednak zwrócić uwagę na to, że wybory polityków powoduja wiarę społeczeństwa w zmianę dotychczasowej polityki ekonomicznej. W efekcie, kiedy politycy stosuja nowe dane do aktualizacji krzywej Phillipsa, położenie nowej krzywej Phillipsa ulegnie zmianie ${ }^{12}$. Dlatego też taki sposób podejmowania decyzji politycznych $\mathrm{z}$ jednoczesną próba znalezienia obecnego położenia na krzywej Phillipsa może faktycznie skutkować wyższą inflacją. Antyinflacyjna polityka jest skutecznym rozwiązaniem, obniżanie przewidywanej inflacji nie generuje bowiem wysokich kosztów ekonomicznych i społecznych, czego T. Sargent dowiódł w swoich badaniach. Inni wybitni ekonomiści reprezentujący szkołę realnego cyklu koniunkturalnego - F. Kydland i E. Prescott - przeprowadzili w 1977 r. badania nad środowiskiem podejmowania decyzji i uprawiania polityki ekonomicznej. Zdaniem F. Kydlanda i E. Prescotta, występuje niespójność optymalizacji polityki ekonomicznej w czasie. Taka polityka osłabia wiarygodność zapowiadanych przez rząd posunięć i powoduje wzrost niepewności w społeczeństwie co do efektów tej polityki. Dlatego też winno się opierać politykę ekonomiczną na zaufaniu społeczeństwa do rządu i na jasnym określeniu zasad oddziaływania polityki ekonomicznej na społeczeństwo i gospodarkę ${ }^{13}$.

W drugiej połowie lat 90. XX w. modele krzywej Phillipsa zainteresowały ekonomistów z kręgu tak zwanej nowej syntezy neoklasycznej. Nurt ten połączył elementy neokeynesizmu i teorii realnego cyklu koniunkturalnego, wskazując na istnienie związków pomiędzy inflacją a aktywnością gospodarczą.

\footnotetext{
11 R. J. Gordon, op. cit., s. 28.

12 T. Sargent, The Conquest of the American Inflation, Princeton University Press, Princeton 1999.

${ }^{13}$ F. Kydland, E. Prescott, Rules rather than Discretion: The Inconsistency of Optimal Plans, „Journal of Political Economy” 85, 1977, nr 3, s. 473-491.
} 
W ramach takiego podejścia zaakceptowano koncepcję racjonalnych oczekiwań i zjawisko konkurencji niedoskonałej na rynkach ${ }^{14}$. Przedstawione do tej pory modele uwzględniały albo prognozy inflacyjne oparte na zjawiskach wcześniejszych, albo wynikające $\mathrm{z}$ predykcji na podstawie przeszłych i bieżących zjawisk. W 1999 r. powstała za sprawa J. Gali i M. Gertlera tak zwana koncepcja hybrydowego modelu krzywej Phillipsa, która uznawana jest za główny przykład wkładu teorii nowej syntezy neoklasycznej do rozwoju krzywej Phillipsa. J. Gali i M. Gertler w swoich badaniach wykazali, że w gospodarce występuja podmioty opierające oczekiwania inflacyjne zarówno na przeszłych wydarzeniach, jak i dokonujące prognoz, wykorzystując teraźniejsze. Krzywa Phillipsa powinna zatem uwzględniać sytuację, w której realna stopa inflacji jest uwarunkowana zarówno przeszłą, jak i przyszłą stopą inflacji ${ }^{15}$. Ciągła inflacja jest efektem ekspansywnej polityki monetarnej. Z kolei ewolucja oczekiwań inflacyjnych podmiotów rynkowych zależy od ewolucji polityki państwa. Jeśli zmiany w polityce są widoczne, a dodatkowo zrozumiałe dla ludzi, to oczekiwania inflacyjne ulegną zmianie.

\section{EMPIRYCZNA WERYFIKACJA KRZYWEJ PHILLIPSA - PRZEGLĄD LITERATURY}

W literaturze przedmiotu prezentowane sa liczne badania empiryczne potwierdzające istnienie zależności między inflacją a bezrobociem. Krytyczna ocena rezultatów tych analiz - zarówno dotyczących gospodarki polskiej, jak i wielu zagranicznych - pozwala sformułować określone wnioski na temat aplikacyjności koncepcji krzywej Phillipsa. Trzeba jednak podkreślić, że doświadczenia odnośnie do gospodarki polskiej nie sa aż tak obszerne, jak te oparte na analizach gospodarek zagranicznych.

Wśród dostępnych prac na temat polskiej gospodarki warto zwrócić uwagę na badania, które zaprezentowali G. Kuczyński i K. Strzała ${ }^{16}$. Badali oni przede wszystkim aktualność teorii krzywej Phillipsa w Polsce. W analizowanym okresie lat 90 . XX w. stwierdzono dodatnią korelację pomiędzy poziomem bezrobocia a inflacją. Był to jednak bardzo szczególny okres transformacji gospodarczej, która miała zauważalny wpływ na poziom bezrobocia. Interesujące badania przeprowadził M. Brycz ${ }^{17}$. Autor dokonał analizy i estymacji modelu Gali-Gertlera $^{18}$, sprawdzając jakość dopasowania parametrów modelu GG (głównie charakterystyk produkcyjnych kosztów krańcowych i sztywności cen Calvo) do polskich realiów gospodarczych w latach 1997-2006. Na podstawie

${ }^{14}$ M. Brycz, Pięćdziesiat lat krzywej Phillipsa, w: Conference Abstracts Economics Challenge of the XXI Century Poland - European Union - World, Międzyzdroje 2008.

15 J. Gali, M. Gertler, Inflation Dynamics: A Structural Econometric Analysis, ,Journal of Monetary Economics" 44, 1999, nr 2, s. 195-222.

${ }^{16}$ G. Kuczyński, K. Strzała, Phillips Curve in Poland. Myth or Fact?, Macromodels 2001 Proceedings, Łódź 2002.

${ }^{17}$ M. Brycz, Dyskusja nad neo-keynesowska krzywa Phillipsa - wnioski dla Polski, w: D. Kopycińska (red.), Zachowania rynkowe $w$ teorii i praktyce, Wydawnictwo Uniwersytetu Szczecińskiego, Szczecin 2007.

18 J. Gali, M. Gertler, op. cit., s. 195-222. 
przeprowadzonych badań można wysnuć wnioski, że w Polsce, w badanym okresie, widoczny był duży wpływ jednostkowego kosztu pracy na inflację oraz charakterystyka krzywej Phillipsa nie odbiega znacząco od krajów strefy euro.

Jeszcze inne wnioski płyną z badań, które przeprowadził T. Grabia ${ }^{19}$. W opublikowanym artykule zawarł próbę analizy wpływu stopy inflacji na stopę bezrobocia w Polsce w latach 1990-2006. Badania te (dotyczące okresu III kwartał 1996 r. - III kwartał 2002 r.), wskazuja na wysoką wartość stopy NAIRU (12-14\%), co świadczy o dużych niedopasowaniach strukturalnych w polskiej gospodarce w rozpatrywanym okresie. Z analiz wynika też, że krzywa Phillipsa bezsprzecznie występowała w Polsce w latach 1998-2003. Oceny co do występowania krzywej Phillipsa w latach wcześniejszych (1990-1997) sa niejednoznaczne: część badaczy wskazuje na występowanie krzywej Phillipsa w latach 1990-1994 (A. Więznowski), z kolei zdaniem innych (M. Góra, E. Kryńska) krzywa Phillipsa nie istniała w Polsce w pierwszej połowie lat 90. ubiegłego wieku.

Dużo większe możliwości poznawcze i analityczne dają wyniki analiz publikowanych za granica. Wśród badań, które koncentrowały się na analizie omawianej zależności w jednej z zagranicznych gospodarek, warto przytoczyć prace G. Debelle'go, J. Vickery'go ${ }^{20}$. Zbadali oni problem nieliniowości krótkookresowej krzywej Phillipsa, bazując na gospodarce australijskiej. Z badań wynika, że krótkookresowa krzywa Phillipsa dla Australii ma charakter nieliniowy (jest wypukła); pokazują też one wpływ nieliniowości modelu Phillipsa na skuteczność polityki monetarnej. Autorzy formułuja pogląd, że nieliniowa krzywa Phillipsa powinna skłaniać do ostrożniejszej polityki monetarnej, zwłaszcza jeśli stosuje się ten model do analizy gospodarki - tak jak australijska - rozwiniętej.

Z kolei J. Gali i J. D. López-Salido zbadali model krzywej Phillipsa dla Hiszpanii w latach 1980-1998 ${ }^{21}$. Konkluzja z badań jest to, że model wykazuje dobre dopasowanie do danych. Artykuł ten stanowi kontynuację prac A. M. Sbordone'a ${ }^{22}$ oraz J. Gali i M. Gertlera ${ }^{23}$, poruszających problem wpływu kosztów krańcowych na dynamikę wahań inflacyjnych, a zatem także na relację między inflacją a bezrobociem. Efektem pracy tych autorów jest ważny wniosek, iż zmiana wartości kosztów krańcowych produkcji stanowi istotną determinantę zmiany wysokości inflacji w badanym okresie. Autorzy wskazuja determinanty zmian wartości kosztów krańcowych produkcji, a co za tym idzie determinanty decydujące o kształcie krzywej Phillipsa, do których można zaliczyć zmiany cen produkcyjnych dóbr importowanych (wywołanych zmianami kursów wymiany) i wahań na rynku pracy (spowodowanych zmiana wysokości płac). Trzeba jednak zauważyć, że o ile badania wcześniejsze

${ }^{19}$ T. Grabia, Rynek pracy $w$ Polsce $w$ okresie transformacji $w$ świetle różnych wariantów Krzywej Phillipsa, w: D. Kopycińska (red.), Wykorzystanie zasobów pracy we wspótczesnej gospodarce, Wydawnictwo Uniwersytetu Szczecińskiego, Szczecin 2007.

${ }^{20}$ G. Debelle, J. Vickery, Is the Phillips Curve a Curve? Some Evidence and Implications for Australia, „Economic Record” 74, 1998, s. 384-398.

${ }^{21}$ J. Gali, J. D. López-Salido, A New Phillips Curve for Spain, „BIS Papers” 2001, nr 3.

${ }^{22}$ A. M. Sbordone, Prices and Unit Labour Costs: A New Test of Price Stickiness, ,Journal of Monetary Economics" 49, 2002, s. 265-292.

${ }^{23}$ J. Gali, M. Gertler, op. cit., s. 195-222. 
podejmują tę problematykę w odniesieniu do danych USA ${ }^{24} \mathrm{i}$ strefy euro ${ }^{25}$, o tyle artykuł ten ma na celu przybliżenie sytuacji panującej w gospodarce hiszpańskiej.

Interesujące badania przeprowadził także K. Bhanthumnavin ${ }^{26}$. Przeanalizował on model krzywej Phillipsa dla Tajlandii w latach 1990-2001. Zasadniczym celem badań było sformułowanie podstaw do prowadzenia w przyszłości skutecznej polityki monetarnej w Tajlandii. Przy okazji stwierdzono zaskakujący brak efektu krzywej Phillipsa przed początkiem kryzysu ekonomicznego z lat 1993-1995 w Azji. Analizę modelu Phillipsa przeprowadził również J. Oh dla gospodarki Korei Południowej w latach 1982-2005 ${ }^{27}$. Dostarcza ona informacji, że po $1997 \mathrm{r}$. gospodarkę tę charakteryzował stabilny, choć względnie niski wzrost gospodarczy (przy niskiej stopie inflacji i wysokich cenach dóbr). Autor postuluje weryfikację poziomu stopy inflacji w celu przywrócenia ekonomicznego wzrostu gospodarczego przy pełnym zatrudnieniu. W tym celu estymuje stopę inflacji w warunkach pełnego zatrudnienia, która określa mianem NAURI (non accelerating unemployment rate of inflation). NAURI ma stanowić alternatywny wskaźnik dla stopy NAIRU. O ile jednak NAIRU znajduje zastosowanie przy określaniu stopy inflacji dla gospodarki o wysokich parametrach wzrostu i wysokiej stopie inflacji, o tyle proponowana stopa NAURI może zostać wykorzystana do szacowania stopy inflacji w stabilnie, choć wolno rozwijającej się gospodarce o niskich wartościach stopy inflacji i wskaźników produkcyjności.

Ciekawe wnioski wypływaja również z badań, które przeprowadzili K. S. Nell ${ }^{28}$, T. Chor Foon i L. Hooi Hooi ${ }^{29}$, S. Bentolila ${ }^{30}$, Z. Khalid ${ }^{31}$, D. Turner i E. Seghezza ${ }^{32}$, W. L. Seyfried i B. T. Ewing ${ }^{33}$ oraz P. Tillmann ${ }^{34}$. Reasumując, wyniki powyższych badań empirycznych ukazuja bardzo eklektyczne podejście do kwestii krzywej Phillipsa. W dużej mierze zależy to od doboru próby badawczej i zastosowanej metody analitycznej. Jednakże nie można też zaprzeczyć, że związek ten w wielu gospodarkach istnieje, tylko zmieniające się uwarunkowania ekonomiczne powoduja, iż ulega on ciągłej zmianie i stąd tak różne opinie w tej kwestii w literaturze przedmiotu.

${ }^{24}$ A. M. Sbordone, op. cit.

25 J. Gali, M. Gertler, op. cit., s. 195-222.

${ }^{26}$ K. Bhanthumnavin, The Phillips Curve in Thailand, St. Antony's College, ,University of Oxford Working Papers" 2002, June.

${ }_{27}$ J. Oh, Inflation Targeting in Stable Growth Economy: The Korean Experience, „,Seoul Journal of Economics" 19, 2006, nr 1, s. 171-197.

${ }^{28}$ K. S. Nell, Structural Change and Nonlinearities in a Phillips Curve Model for South Africa, „Contemporary Economic Policy” 24, 2006, nr 4, s. 600-617.

${ }^{29}$ T. Chor Foon, L. Hooi Hooi, Is the Phillips Curve Stable for Malaysia? New Empirical Evidence, „Malaysian Journal of Economic Studies” 44, 2007.

${ }^{30}$ S. Bentolila, Does Immigration Affect the Phillips Curve? Some Evidence for Spain, „European Economic Review” 52, 2008, nr 8 (November), s. 1398-1423.

${ }^{31}$ Z. Khalid, Inflation, Unemployment and the NAIRU in Pakistan (1975-2009), „International Journal of Economics and Finance" 3, 2011, nr 1 (February), s. 245-254.

${ }^{32}$ D. Turner, E. Seghezza, Testing for a Common OECD Phillips Curve, „OECD Economics Department Working Papers" 1999, nr 219.

${ }^{33}$ W. L. Seyfried, B. T. Ewing, A Time-Varying Volatility Approach to Modeling the Phillips Curve: A Cross-Country Analysis, ,Journal of Economics and Finance” 28, 2004, nr 2.

${ }^{34}$ P. Tillmann, The New Keynesian Phillips Curve in Europe: Does It Fit or Does It Fail?, Deutsche Bundesbank, Frankfurt am Main 2005. 


\section{PRZEBIEG INFLACJI I BEZROBOCIA W POLSCE W LATACH 1990-2010}

Od początku transformacji ustrojowej w Polsce zjawiska bezrobocia i inflacji znajdowały się w centrum uwagi. W latach 90 . XX w. stanowiły one dość ważny problem ekonomiczny, szczególnie z punktu widzenia efektywnego funkcjonowania polskiej gospodarki. W ostatnim dziesięcioleciu problem inflacji generalnie zmalał, choć nie został całkowicie wyeliminowany, natomiast nadal nie rozwiązano problemu nadmiernego bezrobocia.

\section{Tabela 1}

Średnia stopa inflacji $(i)$ i średnia stopa bezrobocia $(b)$ w latach 1991-2010 (\%)

\begin{tabular}{|c|c|c|}
\hline Okres & $\boldsymbol{i}$ & $\boldsymbol{b}$ \\
\hline $1991-1995$ & 39,4 & 14,7 \\
\hline $1996-2000$ & 12,1 & 12,3 \\
\hline $2001-2005$ & 2,3 & 18,8 \\
\hline $2006-2010$ & 2,5 & 11,9 \\
\hline
\end{tabular}

Za wartość średnią stopy inflacji i stopy bezrobocia przyjęto średnią geometryczną w kolejnych pięcioleciach w latach 1991-2010.

Źródło: opracowanie własne na podstawie danych GUS-u.

Dane zawarte w tabeli 1 pokazują wzajemne relacje średniej wartości stopy inflacji i stopy bezrobocia w Polsce w poszczególnych pięcioletnich okresach, począwszy od $1991 \mathrm{r}$. Z danych tych można wywnioskować, że stopa inflacji została w ostatnim pięcioleciu (średnia wartość w latach 2006-2010) obniżona do około $2,5 \%$, natomiast stopa bezrobocia pozostała na poziomie około $12 \%$.

Zgodnie z pierwotnymi założeniami krzywej Phillipsa przyjmuje się ujemną zależność między stopa inflacji a stopa bezrobocia. Wykresy 1-3 obrazuja kształtowanie się tych kategorii w latach 1991-2010 w gospodarce polskiej. Korzystając $\mathrm{z}$ danych miesięcznych, zauważamy cykliczny rozwój stopy bezrobocia, która po początkowym gwałtownym wzroście - głównie jako efekt transformacji ustrojowo-gospodarczej - osiagnęła pierwszy szczyt na poziomie około $17 \%$ w latach 1993-1994. W tym też czasie można było zaobserwować ujemną zależność między inflacją a bezrobociem - inflacja wykazywała tendencję malejąca - co przynajmniej graficznie wydawało się przybliżeniem zależności omawianej w ramach krzywej Phillipsa.

W kolejnych latach zaobserwowano spadek stopy bezrobocia do poziomu niewiele poniżej 10\% (1998-1999), przy jednoczesnym obniżeniu inflacji, co z kolei oznaczało zaprzeczenie wspomnianej koncepcji krzywej Phillipsa. Następnie w okresie 1999-2004 stopa bezrobocia ponownie zaczęła wzrastać efekt recesji występującej na przełomie wieków - i osiągnęła około 19\% w 2004 r., co przy nadal zniżkującej inflacji mogło oznaczać ponowne 
zachowanie się analizowanych kategorii zgodnie z krzywą Phillipsa. Kolejne lata to gwałtowny spadek bezrobocia $\mathrm{w}$ związku $\mathrm{z}$ otwarciem się kilku zachodnich rynków pracy dla Polaków oraz poprawą koniunktury makroekonomicznej na świecie.

\section{Wykres 1}

Stopa inflacji i stopa bezrobocia w Polsce w latach 1991-1994 (\%; dane roczne)

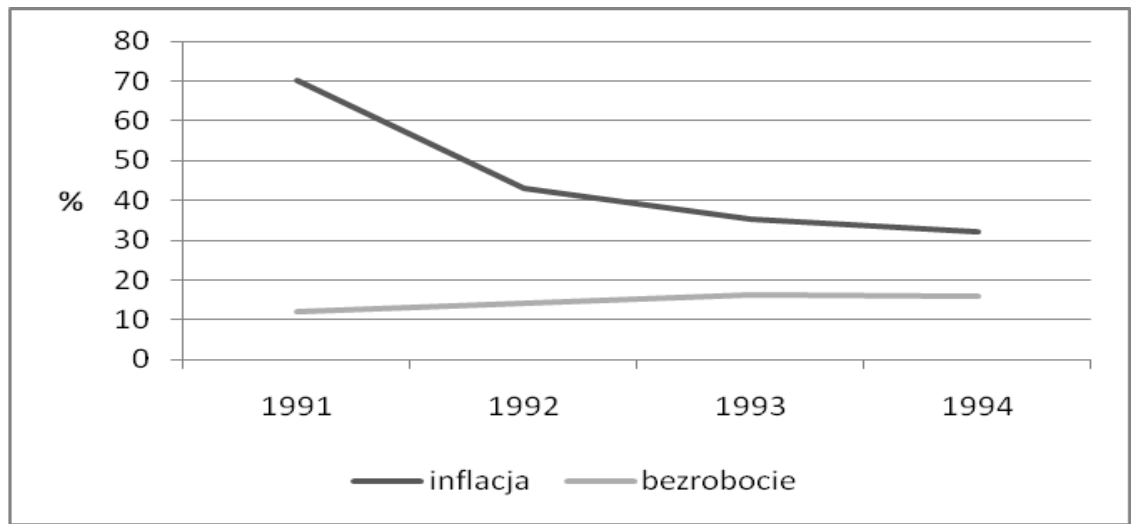

Źródło: opracowanie własne na podstawie danych GUS-u.

\section{Wykres 2}

Stopa inflacji i stopa bezrobocia w Polsce w latach 1995-1999 (\%; dane roczne)

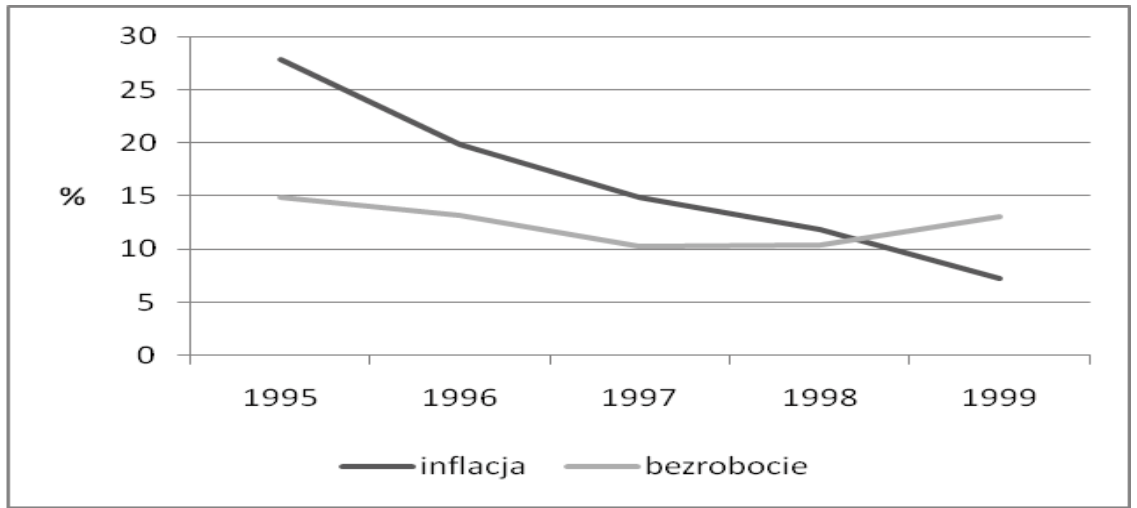

Źródło: opracowanie własne na podstawie danych GUS-u.

Warto podkreślić, że w latach 2005-2006 zaobserwowano zakłócenie ujemnej zależności między inflacją a bezrobociem - jednoczesny spadek obydwu kategorii - na co silny wpływ mogły mieć czynniki instytucjonalne, związane z przystąpieniem Polski do Unii Europejskiej w 2004 r. Na przełomie lat 


\section{Wykres 3}

Stopa inflacji i stopa bezrobocia w Polsce w latach 2000-2010 (\%; dane roczne)

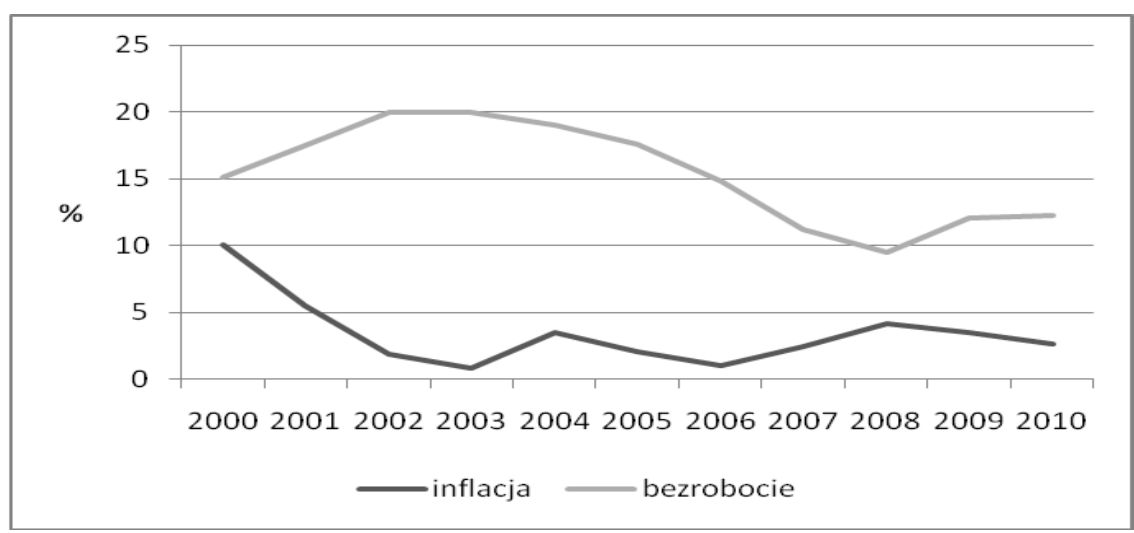

Źródło: opracowanie własne na podstawie danych GUS-u.

2007-2009 stopa bezrobocia osiągnęła jeden z najniższych poziomów od początku transformacji, natomiast stopa inflacji zanotowała najwyższy poziom od 2004 r. Jednak kryzys na światowych rynkach finansowych i pogorszenie koniunktury gospodarczej spowodowały ponowny wzrost bezrobocia, przy jednoczesnym obniżaniu się inflacji w latach 2009-2010. Okres rozwoju inflacji i bezrobocia w Polsce w latach 2007-2010 można uznać, na podstawie oceny graficznej, za przynajmniej częściowo zgodny z założeniami krzywej Phillipsa.

\section{METODA BADAWCZA}

\section{Informacje ogólne dotyczące danych statystycznych}

W pracy zostały wykorzystane dane Głównego Urzędu Statystycznego w Warszawie (GUS) dotyczące stopy bezrobocia oraz stopy inflacji w gospodarce polskiej w latach 1990-2010. Wykorzystane w pracy szeregi czasowe zostały sprawdzone pod względem stacjonarności za pomoca testu Dickeya-Fullera $(\mathrm{ADF})$ oraz testu Phillipsa-Perrona (PP) ${ }^{35}$.

Zastosowanie testu Dickeya-Fullera wymaga braku autokorelacji składnika losowego $\varepsilon_{t}$. Autokorelacji towarzyszy niska (poniżej 0,5) wartość statystyki Durbina-Watsona:

$$
D W=\frac{\sum_{t=2}^{n}\left(y_{t}-y_{t-1}\right)^{2}}{\sum_{t=1}^{n}\left(y_{t}-\bar{y}_{t}\right)^{2}} .
$$

${ }^{35}$ M. Kośko, M. Osińska, J. Stempińska, Ekonometria wspótczesna, Towarzystwo Naukowe Organizacji i Kierownictwa, Stowarzyszenie Wyższej Użyteczności, Dom Organizatora, Toruń 2007, s. 313-318. 
Model szeregu potrzebny do przeprowadzenia testu Dickeya-Fullera możemy zapisać $\mathrm{w}$ postaci:

$$
\Delta y_{t}=\delta y_{t-1}+\varepsilon_{t} .
$$

Skuteczniejsza jest często zmodyfikowana wersja testu Dickeya-Fullera, zwana rozszerzonym testem Dickeya-Fullera (ADF), w której model odpowiedniego szeregu można zapisać następująco:

$$
\Delta y_{t}=\delta y_{t-1}+\sum_{j=1}^{k} \alpha_{j} \Delta y_{i-j}+\varepsilon_{t} .
$$

W teście ADF: $\left(y_{t}\right)$ jest badanym szeregiem, $k$ - liczbą opóźnionych wartości przyrostów zmiennej, którą należy tak dobrać, aby można było wyeliminować autokorelację składnika losowego $\varepsilon_{t}$.

Z kolei w przypadku testu Phillipsa-Perrona podstawowa regresja ma postać:

$$
\Delta y_{t}=\alpha+\beta y_{t-1}+\varepsilon_{t} .
$$

Szczegółowy opis tego testu zawierają prace P. C. B. Phillipsa i P. Perrona ${ }^{36}$ oraz J. D. Hamiltona ${ }^{37}$.

\section{Model teoretyczny}

Do potwierdzenia obowiązywania krzywej Phillipsa wykorzystano model korekty błędem (Error Correction Model - ECM), sprawdzający relację długookresowa między stopami bezrobocia a inflacji. ECM wymaga $\mathrm{w}$ tym wypadku mocnych założeń odnośnie do zintegrowania szeregów czasowych stóp bezrobocia i inflacji. Zgodnie $\mathrm{z}$ tym niestacjonarny szereg czasowy $\left(y_{t}\right)$ jest zintegrowany (stopnia 1) wtedy i tylko wtedy, gdy szereg jego przyrostów $\left(\Delta y_{t}=y_{t}-y_{t-1}\right)$ jest stacjonarny ${ }^{38}$. Przykładem takiego szeregu jest błądzenie przypadkowe postaci:

$$
y_{t}=y_{t-1}+\varepsilon_{t}, \quad i=1,2, \ldots, n,
$$

gdzie $\varepsilon_{t}$ oznacza biały szum, czyli szereg stacjonarny o średniej wartości równej zeru ${ }^{39}$.

Jeżeli szeregi czasowe $\left(x_{t}\right)$ i $\left(y_{t}\right)$ są zintegrowane, to są one skointegrowane wtedy i tylko wtedy, gdy ${ }^{40}$ :

${ }^{36}$ P. C. B. Phillips, P. Perron, Testing for a Unit Root in Time Series Regression, „Biometrika” 75, 1988, s. 335-346.

${ }^{37}$ J. D. Hamilton, Time Series Analysis, Princeton University Press, Princeton 1994.

${ }^{38}$ M. Kośko, M. Osińska, J. Stempińska, op. cit., s. 304.

${ }^{39}$ Ibidem, s. 300.

${ }^{40}$ R. F. Engle, C. W. J. Granger, Co-Integration and Error Correction: Representation, Estimation, and Testing, „Econometrica” 55, 1987, nr 2, s. 251-276. 


$$
y_{t}=\beta_{1}+\beta_{2} x_{t}+v_{t}
$$

gdzie szereg $\left(v_{t}\right)$ jest stacjonarny, $\beta_{1}, \beta_{2} \in R$.

Kointegracja szeregów czasowych oznacza istnienie ich długookresowej zależności (ścieżki równowagi) niezależnej od czasu $t$. Wartości poza tą ścieżką są krótkookresowymi odchyleniami od stanu równowagi. Innymi słowy, szeregi skointegrowane ,niewiele” się od siebie różnią.

Model postaci:

$$
\Delta y_{t}=\gamma \Delta x_{t}+\alpha\left[y_{t-1}-\left(\beta_{1}+\beta_{2} x_{t-1}\right)\right]+\varepsilon_{t},
$$

gdzie szeregi czasowe $\left(x_{t}\right)$ i $\left(y_{t}\right)$ sa zintegrowane, a $\varepsilon_{t}$ jest białym szumem, nazywamy ECM. Model ten składa się z dwóch równań:

1) równania kointegrującego:

$$
y_{t}=\beta_{1}+\beta_{2} x_{t}+v_{t}
$$

zwanego długookresowym, gdzie szereg $\left(v_{t}\right)$ jest stacjonarny, $\beta_{1}, \beta_{2} \in R$;

2) równania krótkookresowego dla przyrostów badanych szeregów:

$$
\Delta y_{t}=\gamma \Delta x_{t}+\alpha E C M_{t-1}+\varepsilon_{t}
$$

gdzie:

$$
E C M_{t-1}=v_{t-1}=y_{t-1}-\left(\beta_{1}+\beta_{2} x_{t-1}\right), \quad \gamma, \alpha, \beta_{1}, \beta_{2} \in R
$$

i $\varepsilon_{t}$ jest białym szumem. Stąd przyrosty $\left(\Delta y_{t}\right)$ szeregu $\left(y_{t}\right)$ wynikaja z:

- przyrostów $\left(\Delta x_{t}\right)$, czyli krótkookresowych fluktuacji (short run),

- błędu dopasowania w równaniu długookresowym (long run).

Wtedy $E C M_{t-1}$ jest składnikiem korekty błędem, który mierzy błąd odchylenia od równowagi długookresowej popełniony w poprzednim okresie $(t-1)$. Stanowi on różnicę postulowanej równowagi oraz rzeczywistych danych. Parametr $\gamma$ informuje o tym, jaka część przyrostu $\left(\Delta x_{t}\right)$ wpływa na przyrost $\left(\Delta y_{t}\right)$. Parametr $\alpha$ informuje o wielkości części odchylenia od równowagi długookresowej wpływającej na przyrost $\left(\Delta y_{t}\right)$. Korekta błędem jest tym mniejsza, im ten parametr jest bliższy zeru. Ostateczny wynik może zachodzić jak poniżej:

1) $-2<\alpha<0$ - następuje powrót do stanu równowagi, gdyż wówczas składnik korekty błędem (różny od zera) koryguje zakłócenie równowagi długookresowej,

2) $\alpha \leqslant-2$ - następuje oscylacja wokół równowagi długookresowej, ale z rosnącą amplitudą wahań,

3) $\alpha \geqslant 0$ - następuje coraz większe odchylenie od równowagi długookresowej, co przeczy występowaniu mechanizmu korekty błędem.

ECM opisuje stan równowagi długookresowej. Działanie tego modelu oznacza, że szeregi czasowe „dopasowują” się do siebie w relacji długookresowej, to znaczy że odpowiednie składniki losowe nie mogą się zwiększać. Na 
podstawie twierdzenia Grangera działanie takiego mechanizmu jest równoważne skointegrowaniu odpowiednich szeregów ${ }^{41}$. Model ten jest dynamiczny i stosuje się go do objaśniania zjawisk reagujących z pewnym opóźnieniem na ich determinanty. Model ten pokazuje, że pojawiające się odchylenia od równowagi długookresowej są korygowane. Aby zbudować ECM należy:

1) zbadać zintegrowanie szeregów czasowych $\left(x_{t}\right)$ i $\left(y_{t}\right)$, czyli niestacjonarność tych szeregów oraz stacjonarność szeregów $\left(\Delta x_{t}\right)$ i $\left(\Delta y_{t}\right)$;

2) jeśli parametry $\beta_{1}$ i $\beta_{2}$ nie są znane, to należy znaleźć ich oszacowania za pomocą metody najmniejszych kwadratów (MNK) oraz wykazać stacjonarność oszacowań szeregu $\left(v_{t}\right)$;

3) za pomoca MNK oszacować parametry $\gamma$ i $\alpha$;

4) zbadać stacjonarność szeregu reszt $\left(\varepsilon_{t}\right)$ i wyznaczyć jego średnią wartość;

5) wykazać, że $\alpha<0$, gdyż tylko wtedy model prowadzi do stanu równowagi.

\section{ANALIZA EMPIRYCZNA}

Dla sprawdzenia aktualności krzywej Phillipsa oraz istnienia odpowiedniej relacji długookresowej pomiędzy stopami bezrobocia i inflacji zbudowano ECM. Zgodnie $\mathrm{z}$ przyjętą $\mathrm{w}$ poprzednim punkcie metodą badawczą przeprowadzono analizę empiryczna. Badania niestacjonarności, stacjonarności oraz oszacowania parametrów wykonano w programie Gretl. Zbiorcze wyniki tych analiz zestawiono $\mathrm{w}$ tabeli 1.

W okresach: I kwartał 1992 - III kwartał 1994 i I kwartał 1999 - I kwartał 2005 , otrzymujemy niestacjonarne szeregi czasowe stóp bezrobocia $\left(b_{t}\right)$ i inflacji $\left(i_{t}\right)$ oraz stacjonarne różnice ich pierwszych przyrostów $\left(\Delta b_{t}\right)$ i $\left(\Delta i_{t}\right)$. Zatem szeregi $\left(b_{t}\right)$ i $\left(i_{t}\right)$ są zintegrowane w stopniu 1 . W obu tych okresach parametr $\beta_{1}$ jest stała równania kointegrującego: równy prognozie stopy bezrobocia przy stopie inflacji wynoszącej $0 \%$. W pierwszym okresie otrzymujemy jego wartość równą $14,9377 \%$, a w drugim wynosi ona $17,5443 \%$. W obu tych okresach parametr $\beta_{2}$ jest ujemny i wynosi, odpowiednio: $-0,2419$ oraz $-1,3696$, co oznacza, że zachodzi efekt krzywej Phillipsa. Zatem wzrostowi (spadkowi) stopy inflacji o 1 punkt procentowy towarzyszy średnio spadek (wzrost) stopy bezrobocia o 0,2419 punktu procentowego w pierwszym okresie oraz o 1,3696 punktu procentowego $\mathrm{w}$ drugim $\mathrm{z}$ nich. A więc $\mathrm{w}$ drugim okresie ujemna korelacja pomiędzy stopami bezrobocia i inflacji jest prawie sześć razy silniejsza niż w pierwszym okresie.

W okresie: I kwartał 1992 - III kwartał 1994, wartość parametru $\gamma$ jest równa $-0,0165$, to znaczy że wówczas 0,0165 wzrostu (spadku) stopy inflacji wpływa na spadek (wzrost) stopy bezrobocia. Z kolei w okresie: I kwartał 1999 I kwartał 2005, wartość parametru $\gamma$ wynosi 0,0045 , to znaczy że wtedy 0,0045 wzrostu (spadku) stopy inflacji wpływa na wzrost (spadek) stopy bezrobocia.

W okresie: I kwartał 1992 - III kwartał 1994, wartość parametru $\alpha$ wynosi $-0,0126$. Zatem 0,0126 odchylenia $\mathrm{w}$ okresie poprzednim $(t-1)$ pomiędzy rzeczywistą wartością stopy bezrobocia a jej wartością teoretyczną wynikająca z równania długookresowego wpływa na przyrost stopy bezrobocia. Z kolei

${ }^{41}$ Ibidem, s. 251-276. 
Tabela 2

Wyniki analizy empirycznej

\begin{tabular}{|c|c|c|c|c|c|c|c|c|}
\hline \multirow{2}{*}{ Parametry } & \multicolumn{7}{|c|}{ Numer estymacji } \\
\cline { 2 - 10 } & $\mathbf{( 1 )}$ & $\mathbf{( 2 )}$ & $\mathbf{( 3 )}$ & $\mathbf{( 4 )}$ & $\mathbf{( 5 )}$ & $\mathbf{( 6 )}$ & $\mathbf{( 7 )}$ & $\mathbf{( 8 )}$ \\
\hline$b_{t}$ & $\mathrm{~N}$ & $\mathrm{~N}$ & $\mathrm{~N}$ & $\mathrm{~N}$ & $\mathrm{~N}$ & $\mathrm{~N}$ & $\mathrm{~N}$ & $\mathrm{~N}$ \\
\hline$i_{t}$ & $\mathrm{~N}$ & $\mathrm{~N}$ & $\mathrm{~N}$ & $\mathrm{~N}$ & $\mathrm{~S}$ & $\mathrm{~S}$ & $\mathrm{~S}$ & $\mathrm{~S}$ \\
\hline$\Delta b_{t}$ & $\mathrm{~S}$ & $\mathrm{~S}$ & $\mathrm{~N}$ & $\mathrm{~N}$ & $\mathrm{~S}$ & $\mathrm{~S}$ & $\mathrm{~S}$ & $\mathrm{~S}$ \\
\hline$\Delta i_{t}$ & $\mathrm{~S}$ & $\mathrm{~S}$ & $\mathrm{~S}$ & $\mathrm{~S}$ & $\mathrm{~S}$ & $\mathrm{~S}$ & $\mathrm{~S}$ & $\mathrm{~S}$ \\
\hline$\beta_{1}$ & 14,9377 & 17,5443 & 10,0587 & 9,1985 & 13,2863 & 13,4912 & 13,5492 & 13,6675 \\
\hline$\beta_{2}$ & $-0,2419$ & $-1,3696$ & $-0,3196$ & 0,2556 & $-0,2361$ & $-0,1109$ & $-0,0431$ & $-0,0177$ \\
\hline$P h i l l i p s$ & + & + & + & - & + & + & + & + \\
\hline$v_{t}$ & $\mathrm{~S}$ & $\mathrm{~S}$ & $*$ & $*$ & $*$ & $*$ & $*$ & $*$ \\
\hline$\gamma$ & $-0,0165$ & 0,0045 & $*$ & $*$ & $*$ & $*$ & $*$ & $*$ \\
\hline$\alpha$ & $-0,0126$ & $-0,1704$ & $*$ & $*$ & $*$ & $*$ & $*$ & $*$ \\
\hline$\varepsilon_{t}$ & $\mathrm{~S}$ & $\mathrm{~S}$ & $*$ & $*$ & $*$ & $*$ & $*$ & $*$ \\
\hline$\varepsilon$ & 0,1739 & 0,2284 & $*$ & $*$ & $*$ & $*$ & $*$ & $*$ \\
\hline$E C M$ & + & + & - & - & - & - & - & - \\
\hline$n$ & 27 & 25 & 24 & 27 & 252 & 84 & 42 & 21 \\
\hline
\end{tabular}

Estymacje: (1) styczeń 1992 - marzec 1994; (2) I kwartał 1999 - I kwartał 2005; (3) październik 2006 - wrzesień 2008; (4) październik 2008 - grudzień 2010; (5) styczeń 1990 - grudzień 2010; (6) I kwartał 1990 - IV kwartał 2010; (7) I półrocze 1990 - II półrocze 2010; (8) 1990-2010 (rocznie); $b_{t}$ - szereg czasowy stóp bezrobocia w gospodarce polskiej w $t$-tym okresie ( $\mathrm{N}$ - szereg niestacjonarny; $\mathrm{S}$ - szereg stacjonarny); $i_{t}$ - szereg czasowy stóp inflacji w gospodarce polskiej $\mathrm{w} t$-tym okresie $(\mathrm{N}$ - szereg niestacjonarny; $\mathrm{S}$ - szereg stacjonarny); $\Delta b_{t}$ - szereg pierwszych przyrostów szeregu czasowego stóp bezrobocia w gospodarce polskiej w $t$-tym okresie $\left(\mathrm{N}\right.$ - szereg niestacjonarny; $\mathrm{S}$ - szereg stacjonarny); $\Delta i_{t}-\mathrm{szereg}$ pierwszych przyrostów szeregu czasowego stóp inflacji w gospodarce polskiej w $t$-tym okresie $(\mathrm{N}-\mathrm{szereg}$ niestacjonarny; $\mathrm{S}$-szereg stacjonarny); $\beta_{1}$ - stała równania kointegrującego; $\beta_{2}$ - parametr przy zmiennej $i_{t}$ w równaniu kointegrującym; Phillips - zachodzenie ujemnej korelacji między stopami bezrobocia a stopami inflacji (,,+” oznacza, że taka korelacja zachodzi, natomiast ,--, że korelacja ta nie zachodzi); $v_{t}$ - szereg reszt $\mathrm{w}$ równaniu kointegrujacym (N - szereg niestacjonarny; $\mathrm{S}$ - szereg stacjonarny); $\gamma$ - parametr przy zmiennej $\Delta i_{t}$ w równaniu krótkookresowym ECM; $\alpha$-parametr przy zmiennej $v_{t-1}$ $\mathrm{w}$ równaniu krótkookresowym ECM; $\varepsilon_{t}$ - szereg reszt w równaniu krótkookresowym $(\mathrm{N}-\mathrm{szereg}$ niestacjonarny; $\mathrm{S}$ - szereg stacjonarny); $\varepsilon$ - średnia wartość szeregu reszt w równaniu krótkookresowym; ECM - możliwość zbudowania modelu korekty błędem (,,+” oznacza, że jest możliwe zbudowanie ECM, natomiast ,--”, że nie ma takiej możliwości); $n$ - liczba obserwacji; * - brak podstaw do budowy ECM.

Źródło: opracowanie własne na podstawie danych GUS-u.

w okresie: I kwartał 1999 - I kwartał 2005, wartość parametru $\alpha$ wynosi $-0,1704$. Stąd, 0,1704 odchylenia w okresie poprzednim $(t-1)$ pomiędzy rzeczywistą wartościa stopy bezrobocia a jej wartością wynikająca z równania długookresowego wpływa na przyrost stopy bezrobocia. W obu tych okresach wartość parametru $\alpha$ jest ujemna, co znaczy, że w każdym z tych przypadków 
następuje powrót do stanu równowagi długookresowej. Przy tym korekta błędu jest oczywiście w drugim okresie około 14 razy większa niż w pierwszym z nich. Ponadto w obu tych przypadkach szereg reszt $\left(\varepsilon_{t}\right)$ jest zbliżony do białego szumu - jest stacjonarny i ma średnią wartość równą, odpowiednio, 0,1739 oraz 0,2284, czyli bliską zeru. Zatem dla obu tych okresów można zbudować ECM, gdyż szereg $\left(v_{t}\right)$ jest stacjonarny, parametr $\alpha$ przyjmuje wartość ujemna, a szereg reszt $\left(\varepsilon_{t}\right)$ jest stacjonarny i o wartości średniej zbliżonej do zera.

W okresie październik 2006 - wrzesień 2008 (przed światowym kryzysem finansowym) zachodzi ujemna korelacja stóp bezrobocia i inflacji: $\beta_{2}=-0,3196$; $\beta_{1}=10,0587$. Zatem wzrostowi (spadkowi) stopy inflacji o 1 punkt procentowy odpowiada średnio spadek (wzrost) stopy bezrobocia o 0,3196 punktu procentowego. A więc zachodzi wtedy efekt krzywej Phillipsa. Prognoza stopy bezrobocia przy stopie inflacji równej $0 \%$ wynosi $10,0587 \%$. Brakuje jednak podstaw do budowy ECM z powodu niestacjonarności szeregu $\left(\Delta b_{t}\right)$.

W okresie październik 2008 - grudzień 2010 (występowanie światowego kryzysu finansowego) szereg $\left(\Delta b_{t}\right)$ jest niestacjonarny, a ponadto nie zachodzi nawet ujemna korelacja stóp bezrobocia i inflacji $\left(\beta_{2}=0,2556 ; \beta_{1}=9,1985\right)$. Sytuacja ta stanowi wyjatek, gdyż w rozpatrywanym okresie nie zaobserwowano efektu krzywej Phillipsa.

Ujemna korelacja między stopami bezrobocia a inflacji w Polsce zachodzi dla danych miesięcznych w całym okresie 1990-2010, gdyż wtedy otrzymujemy $\beta_{2}=-0,2361$. Zatem wzrostowi (spadkowi) stopy inflacji o 1 punkt procentowy odpowiada wtedy średnio spadek (wzrost) stopy bezrobocia o 0,2361 punktu procentowego. Ponadto $\beta_{1}=13,2863$, skąd wynika, że prognoza stopy bezrobocia przy stopie inflacji równej $0 \%$ wynosi $13,2863 \%$. Dla danych kwartalnych z lat 1990-2010 otrzymujemy, odpowiednio, $\beta_{2}=-0,1109 ; \beta_{1}=13,4912$. Zatem wzrostowi (spadkowi) stopy inflacji o 1 punkt procentowy odpowiada wtedy średnio spadek (wzrost) stopy bezrobocia o 0,1109 punktu procentowego, a prognoza stopy bezrobocia przy stopie inflacji równej $0 \%$ wynosi $13,4912 \%$.

Dla danych półrocznych $\mathrm{z}$ lat 1990-2010 otrzymujemy odpowiednio $\beta_{2}=-0,0431 ; \beta_{1}=13,5492$. Zatem wzrostowi (spadkowi) stopy inflacji o 1 punkt procentowy odpowiada wtedy średnio spadek (wzrost) stopy bezrobocia o 0,0431 punktu procentowego, a prognoza stopy bezrobocia przy stopie inflacji równej $0 \%$ wynosi $13,5492 \%$. Dla danych rocznych $\mathrm{z}$ lat 1990-2010 otrzymujemy, odpowiednio, $\beta_{2}=-0,0177 ; \beta_{1}=13,6675$. Zatem wzrostowi (spadkowi) stopy inflacji o 1 punkt procentowy odpowiada wtedy średnio spadek (wzrost) stopy bezrobocia o 0,0177 punktu procentowego, a prognoza stopy bezrobocia przy stopie inflacji równej $0 \%$ wynosi $13,6675 \%$.

Jednakże dla danych miesięcznych, kwartalnych, półrocznych i rocznych z całego okresu 1990-2010, z powodu braku zintegrowania szeregów czasowych stóp inflacji, nie można zbudować ECM, który wzmacniałby efekt krzywej Phillipsa. A to oznacza, że pojawiające się $\mathrm{w}$ tych (i wielu jeszcze innych przypadkach) odchylenia od równowagi długookresowej mogły nie być korygowane. 


\section{WNIOSKI}

Ewolucja krzywej Phillipsa na przestrzeni omawianego półwiecza objęła wiele aspektów dopełniających obecny sposób jej postrzegania: mikro- i makroskalę, związki z krótkim i długim okresem, wpływ na decyzje podmiotów gospodarujących, rozmaite kierunki polityki ekonomicznej, wreszcie wkład w rozwój charakterystyk podstawowych wartości związanych z krzywą Phillipsa (stopami inflacji, bezrobocia, produkcja, zatrudnieniem, cenami, płacami, równowagą rynkową). Poniżej, tytułem podsumowania, zarysowano najważniejszy wkład poszczególnych doktryn i badaczy w rozwój krzywej Phillipsa od jej powstania w $1958 \mathrm{r}$. aż po przełom XX i XXI w.

A. W. Phillips dokonał obserwacji wskazującej na występowanie odwrotnej relacji między stopa bezrobocia a stopa płac nominalnych wobec malejącej sztywności płac. Wskazał, że zmiana płac jest determinowana nie tylko bieżącym poziomem bezrobocia, ale też tempem zmian jego stopy. Podążającym w jego kierunku P. Samuelsonowi i R. Solowowi współczesna ekonomia zawdzięcza nie tylko termin ,krzywa Phillipsa”, ale przede wszystkim badania nad zależnościami między tempem wzrostu płac nominalnych a tempem wzrostu cen. Wskazali oni ponadto na możliwość przesuwania krzywej Phillipsa w dół przy wzroście elastyczności rynku pracy. Dalszy rozwój koncepcji krzywej Phillipsa nastąił za sprawa M. Friedmana i E. Phelpsa. Krzywa Phillipsa zyskała wymiar „długookresowy”, uwzględniając naturalną stopę bezrobocia. Ponadto dzięki tym badaczom dotychczasowy model krzywej Phillipsa uzupełniony został o hipotezę oczekiwań adaptacyjnych. Neokeynesizm postulował długookresową neutralność świadomie uwzględniającą rolę szoków podażowych w zmianach położenia krzywej Phillipsa. Wskazywał na występowanie relacji stopy inflacji do oczekiwań inflacyjnych, będącej efektem zmian poglądów ekonomicznych podmiotów gospodarczych i wolnego procesu dostosowawczego płac i cen. Znajdujący się w opozycji do powyższego nurtu R. Lucas wzbogacił teorię o wpływ racjonalnych zachowań podmiotów gospodarczych na położenie krzywej Phillipsa. W ramach nowej ekonomii klasycznej założono występowanie doskonałej racjonalności podmiotów gospodarczych, wskazując jednocześnie na nieskuteczność polityki ekonomicznej w zakresie wpływu na charakterystykę krzywej Phillipsa. Zwolennik teorii realnego cyklu koniunkturalnego T. Sargent postawił tezę, że polityka ekonomiczna, a tym samym funkcjonowanie krzywej Phillipsa, opiera się na przeszłych spostrzeżeniach decydentów, a prowadzenie polityki antyinflacyjnej jest procesem skutecznie obniżającym długookresową krzywą Phillipsa. Natomiast F. Kydland i E. Prescott wskazali na niespójność polityki ekonomicznej w czasie, a teoria nowej syntezy neoklasycznej - myśl schyłku XX w. - uzupełniła model krzywej Phillipsa o hybrydowe ujęcie oczekiwań zmian stóp inflacji.

W części empirycznej niniejszej pracy sprawdzono aktualność krzywej Phillipsa dla danych o miesięcznych, kwartalnych, półrocznych i rocznych stopach bezrobocia oraz inflacji dla Polski w okresie 1990-2010. Ponadto starano się wzmocnić efekt krzywej Phillipsa, wykorzystując model korekty błędem. Niestety zbudowanie takiego modelu okazało się niewykonalne w większości 
przypadków $\mathrm{z}$ powodu niespełnienia $\mathrm{w}$ badanych okresach odpowiednich warunków przez szeregi czasowe stóp bezrobocia oraz inflacji. Zatem, pomimo istnienia odpowiedniej relacji długookresowej pomiędzy stopami bezrobocia i inflacji, badania wskazuja, że mogła nie zachodzić korekta odchylenia od równowagi długookresowej. Ponadto, w pracy pokazano, że w okresie światowego kryzysu finansowego nie wystapił w Polsce nawet efekt samej krzywej Phillipsa. Jedynie w okresach: I kwartał 1992 - III kwartał 1994 i I kwartał 1999 - I kwartał 2005 (oraz w wielu ich podokresach) możliwe było zbudowanie modelu korekty błędem.

mgr Maciej Mańkowski

Uniwersytet Ekonomiczny w Krakowie

dr Andrzej Ostrowski

Uniwersytet Opolski

dr Robert W. Wtodarczyk

Uniwersytet Ekonomiczny w Krakowie

\section{THE RELATIONSHIP BETWEEN UNEMPLOYMENT AND INFLATION IN POLAND AND THE PHILLIPS CURVE}

\section{Summary}

The theoretical part of the paper presents the evolution of the views on Phillips curve. The model of 1958 has been described and its further developments proposed by a number of economists, including P. Samuelson, R. Solow, M. Friedman, E. Phelps, R. Lucas, E. Kydland, and E. Prescott, have been discussed, followed by a general review of the international literature pertaining to the empirical examination of the Phillips curve.

The goal of the empirical part is to examine the existence of Phillips curve in Polish economy in 1990-2010. The direction and ties between the inflation rate and employment rate has been analysed based on monthly, quarterly, semi-annual and annual data. The minimal square model and the error correction model were used in the analysis. It has been found that not even the effect of Phillips curve occurred in Poland during the world financial crisis. Only between the first quarter of 1992 and the third quarter of 1994 and between the first quarter of 1999 and the first quarter of 2005, and several sub-periods, the model could have been built by error. 
